ORIGINAL ARTICLE

\title{
Non-random asynchronous replication at $22 q 11.2$ favours unequal meiotic crossovers leading to the human $22 q 11.2$ deletion
}

\author{
A Baumer*, M Riegel*, A Schinzel
}

J Med Genet 2004;41:413-420. doi: 10.1136/jmg.2003.016352

See end of article for authors' affiliations

Correspondence to: $\operatorname{Dr}$ A Baumer, Institute of Medical Genetics, University of Zurich, Schorenstrasse 16, CH-8603 Schwerzenbach, Switzerland; baumer@ medgen.unizh.ch

Revised version received 16 January 2004 Accepted for publication 18 February 2004

\begin{abstract}
Background: Analyses of the replication timing at $22 q 11.2$ were prompted by our finding of a statistically significant bias in the origin of the regions flanking the deletion site in patients with $22 q 11.2$ deletions, the proximal region being in the majority of cases of grandmaternal origin. We hypothesised that asynchronous replication may be involved in the formation of the 22q11.2 deletion, the most frequently occurring interstitial deletion in humans, by favouring the mispairing of low-copy repeats.

Methods: Replication timing during $S$ phase at $22 q 11.2$ was investigated by fluorescent in situ hybridisation on interphase nuclei. We report on the detection of non-random asynchronous replication at the human chromosome region $22 q 11.2$, an autosomal locus believed not to contain imprinted genes. Results: Asynchronous replication at 22q 11.2 was observed without exception in all 20 tested individuals; these comprised individuals with structurally normal chromosomes 22 (10 cases), individuals with translocations involving the locus 22q11.2 (eight cases), and patients with a $22 q 11.2$ deletion (two cases). The non-random nature of the asynchronous replication was observed in all individuals for whom the chromosomes 22 were distinguishable. The earlier replicating allele was found to be of paternal origin in all cases where the parental origin of the translocation or deletion was known.
\end{abstract}

R eplication of the genome is a highly regulated process Whilst the vast majority of chromosome loci replicate synchronously, asynchronous replication in normal cells is a phenomenon known to be associated with allelic exclusion. Indeed, asynchronous replication has been reported for the $\mathrm{X}$ chromosomes in females, ${ }^{1}$ at autosomal regions containing imprinted genes, ${ }^{2-4}$ at olfactory receptor genes, ${ }^{5}$ and the murine B cell receptor loci. ${ }^{6}$ In contrast to the random allelic exclusion of the two $\mathrm{X}$ chromosomes and the non-imprinted autosomal loci, each parental allele at loci containing imprinted genes is specifically either early or later replicating. We report on the detection of non-random asynchronous replication at the human chromosome region 22q11.2. The locus is believed not to contain imprinted genes based on the normal phenotypes associated with uniparental disomy $22^{7}$ and the lack of parent-of-origin specific phenotypes in patients with hemizygous 22q11.2 deletions. Allelic exclusion at B cell receptor gene loci in mice was recently reported. ${ }^{6}$ Interestingly, a number of genes involved in the immune response are contained in the human $22 \mathrm{ql} 1.2$ region; however, the findings of Mostoslavsky et $a l^{6}$ show a random pattern of allelic exclusion.

Based on the results presented here we suggest that the asynchronous replication at $22 \mathrm{q} 11.2$ is associated with the formation of the human 22q11.2 deletion. The 22q11.2 deletions appear to arise by mispairing of highly homologous regions, low-copy repeats (LCR), flanking a region of about $3 \mathrm{Mb}^{8}$ The proximal breakpoint is common to the vast majority of 22q11.2 deletions (approximately 97\%), whereas at least three different distal breakpoints have been described, one being by far the most common. ${ }^{8}$ A statistically significant number of 22q11.2 deletions appear to arise by unequal meiotic crossovers. ${ }^{9}$

A deletion of $1.5 \mathrm{Mb}$ at $7 \mathrm{ql} 1.23$ represents a further frequently observed microdeletion in humans, associated with Williams-Beuren syndrome, which we have previously shown to be also associated with unequal meiotic recombination events. ${ }^{10}$ Furthermore, chromosome 7 contains imprinted genes at 7p11.2-p12 and at 7q32. A recent study showed that a polymorphism at $7 \mathrm{ql} 1.23$ consisting of an inversion was detected in $33 \%$ of parents who transmitted the abnormal chromosome. ${ }^{11}$ Similarly, an inversion polymorphism was detected in a significant number of mothers of Angelman syndrome patients with a maternal 15q11-q13 deletion. ${ }^{12}$ However, an inversion of the critical region was not detected in the parents of 18 patients with the $22 \mathrm{q} 11.2$ deletion. ${ }^{13}$ The inversions at $7 q 11.23$ and 15q11-q13 could possibly represent a risk factor for the occurrence of a deletion by reducing the recombination frequency. Indeed, mispairing of repeat elements appears to be favoured by reduced meiotic recombination frequencies. Evidence has been shown of reduced recombination frequencies at $17 \mathrm{pl} 12$ associated with the CMT1A duplication/HNPP deletion ${ }^{14}$ and at 17pll.2 associated with the Smith-Magenis syndrome deletion. ${ }^{15}$

\section{METHODS}

\section{Microsatellite analysis}

We included in the study all patients with a de novo hemizygous 22q11.2 deletion for whom parental and grandparental blood samples were available (20 cases, table 1). Patients $1-8,18$, and 19 were already included in a previous study. ${ }^{9}$ The first case refers to two affected monozygous twins, who are considered as a single proband for the purposes of this study. DNA was extracted using standard procedures from peripheral blood lymphocytes of the patients, their parents, and after having established the parental origin of the deletion also from the relevant grandparents. Informed consent was obtained from the adults and the parents of the underage patients. The origin of the deletion was analysed by microsatellite analysis based on the alleles of the patients and their parents. The following markers were used: D22S1638, D22S941, D22S944, and

Abbreviation: LCR, low-copy repeats 
D22S264. The grandparental samples were included in the investigations of the haplotypes of the regions flanking the breakpoints. Microsatellites at the proximal region included: F8VWFP, D22S427, and D22S420; microsatellites at the distal breakpoint region included: D22S303,D22S343, D22S306, and D22S539. Microsatellite analysis was performed as described in a previous publication. ${ }^{9}$

\section{Fluorescent in situ analysis}

Peripheral blood samples drawn from 20 individuals were analysed after obtaining informed consent: 10 healthy control individuals (cases 21-30), eight unaffected individuals with balanced translocations $(\mathrm{t}(6 ; 22), \mathrm{t}(11 ; 22)$ and $\mathrm{t}(19 ; 22))$ involving the $22 \mathrm{ql} 1.2$ region (cases $31-38$ ), and two patients with the common 22q11.2 deletion (cases 13 and 17).

Analysis of the replication pattern by BrdU incorporation was performed following standard procedures. ${ }^{16}$ Probes were used mapping within the deleted region (LSI DiGeorge/VCFS Region Probe (TUPLE 1; Vysis), ZNF74, and "D22S936") and at flanking positions ("D22S427" and ARSA (Vysis)). The probes "D22S427", ZNF74 and "D22S936" each consist of pools of five different PCR products of about 400-500 bp, amplified from a region covering about $10 \mathrm{~kb}$ of genomic sequence. The probes are denoted based on known markers contained in the respective regions. ${ }^{817}$ Oligonucleotide sequences and PCR conditions are provided in table 2 . Different combinations of probes were used (tables 3 and 4), which were scored individually and in pairs. The location of the signals in the nuclei ${ }^{18}{ }^{19}$ as well as the distance between the signals allowed differentiation between the two chromosomes 22 (examples are shown in fig 1).

Probes used for assaying the replication timing at the control regions 7q11.23, 5p15.2, 15q12, and Xp22.3 were LSI Elastin/D7S486 (elastin gene), LSI D5S23, LSI SNRPN/ D15Z1/PML Probe (SNRPN), and LSI Steroid Sulfatase (STS), respectively (all probes were purchased from Vysis).

\section{RESULTS}

Bias in the origin of the regions flanking the $22 q 11.2$ deletions

We initially postulated that the human autosomal region 22 q11.2 replicates asynchronously based on the results we obtained by studying the mode and time of formation of 22 q11.2 deletions. The study involved determination of the parental origin of the de novo hemizygous 22q11.2 deletions in 20 probands followed by analysis of the haplotype segregation at the regions flanking the deletion breakpoints. This latter analysis revealed the presence of an interchromosomal recombination in 17 cases, whereas an intrachromosomal rearrangement was detected only in three cases (table 1). The average distance between the informative markers closest to the deletion breakpoint was approximately $8.8 \mathrm{cM}$. Thus, the chances of observing 17 or more meiotic crossovers in this region in a group of 20 control individuals would be $p=1.0 \times 10^{-15}$. The results obtained in this study based on an increased number of 22q11.2 deletion cases corroborate our previous finding 9 that a significant number of 22 q11.2 deletions are associated with an unequal meiotic recombination. Interestingly, a statistically significant bias in the parental origin of the proximal and distal positions emerged from the data collected: in 15 of the 17 cases where an interchromosomal crossover occurred at the deletion site, the proximal region was derived from the grandmother and only in two cases from the grandfather $\left(\mathrm{p}=1.1 \times 10^{-3}\right.$, $\left.\chi^{2}=9.95\right)$.

We suggested that the most plausible reason for this bias is an asynchronous replication of the $22 \mathrm{q} 11.2$ region.

\section{Proposed model for the formation of the human $22 q 11.2$ deletion}

Schematically illustrated in fig 2 is the proposed model for a mispairing event occurring during meiosis in a parental gamete. Assuming that the initial configuration leading to a mispairing event occurs while the replication forks have already passed both parental LCRI and LCRII on the paternal homologue but have not yet passed the LCRII on the maternal allele, then mispairing of the paternal LCRII with the maternal LCRI would be favoured as compared to the mispairing of the maternal LCRII and the paternal LCRI. The mispairing would then be the basis for an unequal crossingover event later in meiosis, giving rise to a 22q11.2 deletion in the zygote with a predominant grandmaternal origin of the proximal region and grandpaternal origin of the distal region.

Table 1 Summary of the microsatellite results obtained for the patients with the $22 q 11.2$ deletion

\begin{tabular}{|c|c|c|c|c|}
\hline Case & Gender & $\begin{array}{l}\text { Parental origin of the } \\
\text { deletion }\end{array}$ & $\begin{array}{l}\text { Grandparental origin of } \\
\text { the proximal region* }\end{array}$ & $\begin{array}{l}\text { Grandparental origin of } \\
\text { the distal region* }\end{array}$ \\
\hline \multicolumn{5}{|c|}{ Cases with a meiotic recombination at the deletion site } \\
\hline 1 & Females $†$ & Maternal & Grandpaternal (F8WWFP) & Grandmaternal (D22S306) \\
\hline 2 & Male & Paternal & Grandmaternal (D22S420) & Grandpaternal (D22S306) \\
\hline 3 & Female & Paternal & Grandmaternal (D22S427) & Grandpaternal (D22S303) \\
\hline 4 & Female & Maternal & Grandmaternal (D22S427) & Grandpaternal (D22S303) \\
\hline 5 & Male & Paternal & Grandmaternal (D22S420) & Grandpaternal (D22S303) \\
\hline 6 & Female & Paternal & Grandmaternal (D22S420) & Grandpaternal (D22S343) \\
\hline 7 & Male & Maternal & Grandmaternal (D22S420) & Grandpaternal (D22S306) \\
\hline 8 & Female & Paternal & Grandmaternal (D22S427) & Grandpaternal (D22S343) \\
\hline 9 & Female & Paternal & Grandmaternal (D22S427) & Grandpaternal (D22S306) \\
\hline 10 & Female & Maternal & Grandmaternal (D22S427) & Grandpaternal (D22S306) \\
\hline 11 & Male & Maternal & Grandmaternal (D22S420) & Grandpaternal (D22S303) \\
\hline 12 & Female & Maternal & Grandpaternal (D22S420) & Grandmaternal (D22S303) \\
\hline 13 & Female & Maternal & Grandmaternal (D22S420) & Grandpaternal (D22S539) \\
\hline 14 & Male & Maternal & Grandmaternal (D22S427) & Grandpaternal (D22S306) \\
\hline 15 & Male & Paternal & Grandmaternal (D22S427) & Grandpaternal (D22S343) \\
\hline 16 & Female & Maternal & Grandmaternal (D22S427) & Grandpaternal (D22S303) \\
\hline 17 & Female & Paternal & Grandmaternal (D22S427) & Grandpaternal (D22S303) \\
\hline \multicolumn{5}{|c|}{ Cases with an intrachromosomal rearrangement at the deletion site } \\
\hline 18 & Male & Maternal & Grandmaternal (D22S427) & Grandmaternal (D22S303) \\
\hline 19 & Female & Paternal & Grandpaternal (D22S427) & Grandpaternal (D22S343) \\
\hline 20 & Male & Maternal & Grandpaternal (D22S427) & Grandpaternal (D22S306) \\
\hline
\end{tabular}




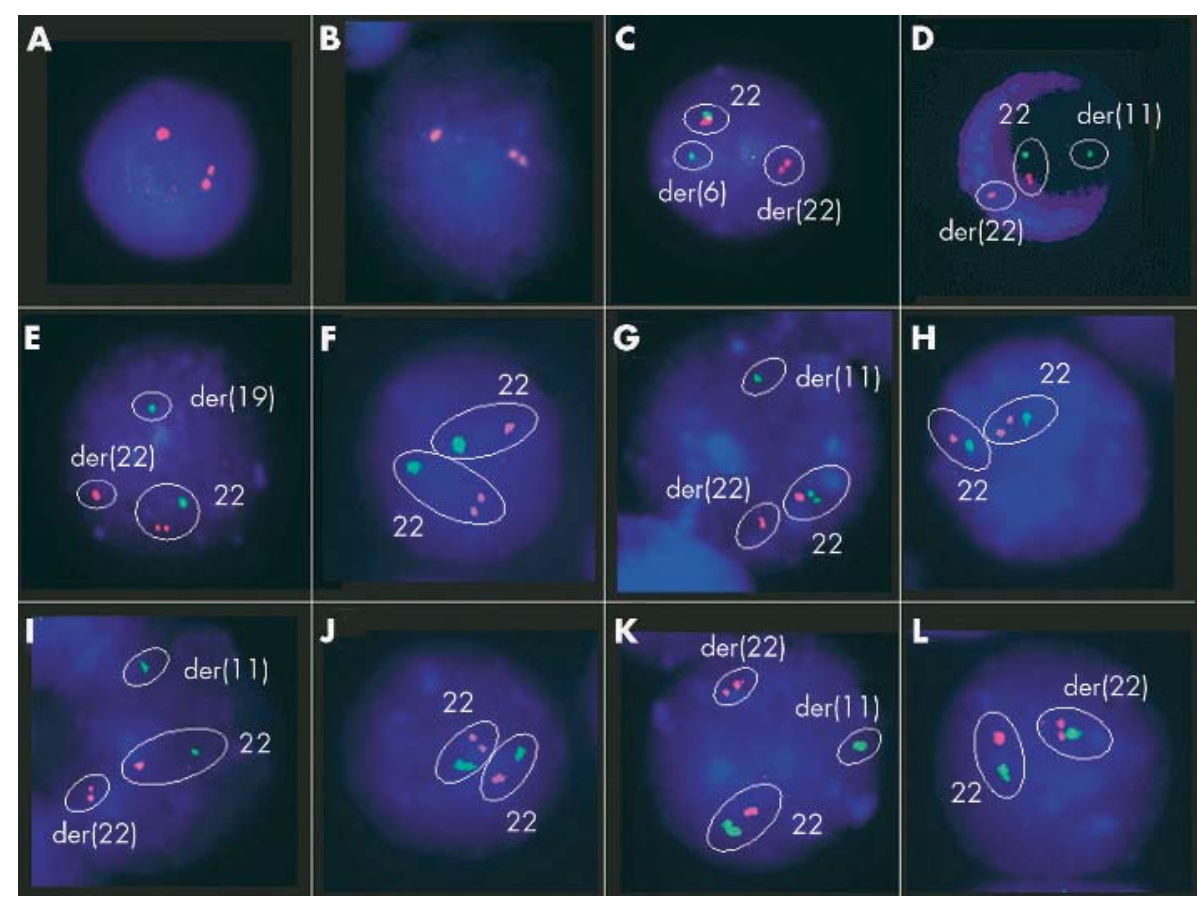

Figure 1 Representative examples of interphase nuclei analysed by fluorescent in situ hybridisation. Nuclei showing a double signal on one chromosome and a single signal on the other chromosome are illustrated for: (A) the LSI DiGeorge/VCFS Region Probe (case 21); (B) control region 7q1 1.23, LSI Williams Syndrome probe (case 21); (C-E) LSI DiGeorge/VCFS Region Probe (red signals) and ARSA, 22q13.3 (green signals) for (C) case 31, (D) case 35, and (E) case 38; (F-G) "D22S427' (red signals) and ZNF74 (green signals) for cases 22 and 32, respectively; (H-I) "D22S427' and "D22S936" (green signals) for cases 22 and 35, respectively; (J-L) "D22S427" and ARSA (green signals) for cases 22, 35, and 17, respectively. In panels $(C)$ to $(L)$, the signals representing the structurally normal chromosome 22 are circled as well as the derivative chromosomes.

\section{Asynchronous replication at human $22 q 11.2$}

Direct evidence for the non-random asynchronous replication during S phase at 22q11.2 was obtained by fluorescent in situ hybridisation on interphase nuclei. Asynchronous replication is inferred when more than about $25 \%$ of nuclei show the presence of two distinct signals (ds) on the homologue that has already gone through replication, while only one signal (ss) is observed on the homologue that has not yet replicated. ${ }^{25}$ The replication timing at $22 \mathrm{q} 11.2$ and 22q13.3 was analysed in peripheral blood cells of 20 individuals, in 10 of whom it was possible to differentiate between the two chromosomes 22 in interphase nuclei, owing either to balanced translocations involving a chromosome 22 (eight individuals) or to a 22q11.2 deletion (two cases).
Analysis of the replication timing in the 10 control individuals with structurally normal chromosomes 22 revealed a high number of nuclei showing a ds/ss pattern (table 3). The mean value obtained for the DiGeorge/VCFS probe was $84.6 \%$ with a $95 \%$ confidence interval (95\% CI) ranging from $82 \%$ to $87.2 \%$. The mean value obtained for the ARSA probe was $76.6 \%$ with a $95 \%$ CI ranging from 73.3 to 79.9. The difference between these values and the generally accepted threshold value of about $25 \%$ for asynchronous replication are strongly significant $(\mathrm{p}<0.0001)$.

Similar high percentages of nuclei with $\mathrm{ds} / \mathrm{ss}$ were detected in individuals with translocations and deletions (table 4), the only exception being the significantly lower values obtained with $22 \mathrm{q}$ probes mapping to the derivative chromosome $1 \mathrm{l}$ in the three individuals with a paternal

Table 2 Oligonucleotide sequences used for the generation of FISH probes

\begin{tabular}{|c|c|c|c|}
\hline \multirow[b]{2}{*}{ Probe } & \multicolumn{2}{|l|}{ Oligonucleotide pairs } & \multirow{2}{*}{$\begin{array}{l}\text { Annealing }{ }^{\circ} \mathrm{C}, \mathrm{PCR} \text { enhancers } \\
\text { if needed and product size }\end{array}$} \\
\hline & Forward $\left(5^{\prime}-3^{\prime}\right)$ & Reverse $\left(5^{\prime}-3^{\prime}\right)$ & \\
\hline "D22S427" & $\begin{array}{l}\text { A: ccaaagcgttgggattac } \\
\text { B: gacccacgagagctgaagac } \\
\text { C: cccgttcatgatttatgtgg } \\
\text { D: gcctggctgcattttacalt } \\
\text { E: gagtcgaaggactttgggagt }\end{array}$ & $\begin{array}{l}\text { A: cacccatgtgtctcagatgc } \\
\text { B: gggtctcagcttcagacag } \\
\text { C: cgatctgagctcactgcaac } \\
\text { D: gactcggctctcggtcctac } \\
\text { E: ggagggtgctgacaaaactg }\end{array}$ & $\begin{array}{l}56^{\circ} \mathrm{C}, 486 \mathrm{bp} \\
56^{\circ} \mathrm{C}+10 \% \mathrm{DMSO}, 477 \mathrm{bp} \\
56^{\circ} \mathrm{C}, 476 \mathrm{bp} \\
56^{\circ} \mathrm{C}, 448 \mathrm{bp} \\
56^{\circ} \mathrm{C}, 494 \mathrm{bp}\end{array}$ \\
\hline ZNF74 & $\begin{array}{l}\text { A: attgggggtagcagctctt } \\
\text { B: tagctcactgcagccttcaa } \\
\text { C: gttccacatgcccttgaaaa } \\
\text { D: ggattlgggttccagtctga } \\
\text { E: gtgttgttggccctattgct }\end{array}$ & $\begin{array}{l}\text { A: gggcaacatctggactcttc } \\
\text { B: gtggittaccaaggggagagg } \\
\text { C: caagagccaaactctgtcaaaa } \\
\text { D: ccagaacaggtctcagcaca } \\
\text { E: gttagggaggccagttaggg }\end{array}$ & $\begin{array}{l}56^{\circ} \mathrm{C}, 479 \mathrm{bp} \\
56^{\circ} \mathrm{C}, 425 \mathrm{bp} \\
56^{\circ} \mathrm{C}, 499 \mathrm{bp} \\
56^{\circ} \mathrm{C}, 453 \mathrm{bp} \\
56^{\circ} \mathrm{C}, 448 \mathrm{bp}\end{array}$ \\
\hline "D22S936" & $\begin{array}{l}\text { A: cacccettcactgcttgagt } \\
\text { B: ctgcagagccacttttgght } \\
\text { C: gcccacccaggataatcttc } \\
\text { D: caggggttaatttggaagga } \\
\text { E: taaagaaccagcctcagtgt }\end{array}$ & $\begin{array}{l}\text { A: agattgtgccactccactcc } \\
\text { B: aatcaaagccctgaatgtgg } \\
\text { C: gggcaacaagagcaaaactc } \\
\text { D: agctcagctctggctctgac } \\
\text { E: tggtggtggaagagaaggac }\end{array}$ & $\begin{array}{l}56^{\circ} \mathrm{C}, 455 \mathrm{bp} \\
56^{\circ} \mathrm{C}, 429 \mathrm{bp} \\
56^{\circ} \mathrm{C}, 477 \mathrm{bp} \\
56^{\circ} \mathrm{C}, 500 \mathrm{bp} \\
56^{\circ} \mathrm{C}, 480 \mathrm{bp}\end{array}$ \\
\hline
\end{tabular}


Table 3 Interphase nuclei of control individuals with structurally normal chromosomes 22 showing a double (ds) and a single signal (ss) for probes within the commonly deleted 22q11.2 region and at flanking positions

\begin{tabular}{|c|c|c|c|c|c|}
\hline \multirow[b]{2}{*}{ Case, gender ${ }^{*}$} & \multirow[b]{2}{*}{ FISH probest } & \multicolumn{3}{|c|}{$\begin{array}{l}\text { Percentage of interphase nucleił showing } \\
\text { either } \mathrm{ds} / \mathrm{ss}, \mathrm{ds} / \mathrm{ds} \text {, or } \mathrm{ss} / \mathrm{ss} \text { for individual probes }\end{array}$} & \multirow{2}{*}{$\begin{array}{l}2 \times \mathrm{ds} \text { on one chr. } 22 \text { and } \\
2 \times \text { ss on the other chr. } 22 \text { for } \\
\text { combinations of two probes } ¥ \S\end{array}$} \\
\hline & & $\mathrm{ds} / \mathrm{ss}$ & $\mathrm{ds} / \mathrm{ds}$ & ss/ss & \\
\hline \multirow{7}{*}{$21, F$} & "D22S427" & $72 \%(201)$ & $7 \%(201)$ & $21 \%(201)$ & \\
\hline & LSI DiGeorge/VCFS & $88 \%(115)$ & $2 \%(115)$ & $10 \%(115)$ & \\
\hline & ZNF74 & $67 \%(101)$ & $15 \%(101)$ & $18 \%(101)$ & \\
\hline & ARSA & $74 \%(201)$ & $2 \%(201)$ & $24 \%(201)$ & \\
\hline & "D22S427" and ZNF74 & & & & $52 \%(101)$ \\
\hline & "D22S427" and ARSA & & & & $57 \%(96)$ \\
\hline & LSI DiGeorge/VCFS and ARSA & & & & $61 \%(100)$ \\
\hline \multirow[t]{9}{*}{$22, \mathrm{~F}$} & "D22S427" & $67 \%(303)$ & $10 \%(303)$ & $23 \%(303)$ & \\
\hline & LSI DiGeorge/VCFS & $89 \%(115)$ & $4 \%(115)$ & $7 \%(115)$ & \\
\hline & ZNF74 & $58 \%(100)$ & $7 \%(100)$ & $35 \%(100)$ & \\
\hline & "D22S936" & $70 \%(91)$ & $3 \%(91)$ & $27 \%(91)$ & \\
\hline & ARSA & $69 \%(209)$ & $8 \%(209)$ & $23 \%(209)$ & \\
\hline & "D22S427" and ZNF74 & & & & $38 \%(98)$ \\
\hline & "D22S427" and "D22S936" & & & & $64 \%(91)$ \\
\hline & "D22S427" and ARSA & & & & $46 \%(106)$ \\
\hline & LSI DiGeorge/VCFS and ARSA & & & & $49 \%(100)$ \\
\hline \multirow{3}{*}{$23, M$} & LSI DiGeorge/VCFS & $84 \%(106)$ & $4 \%(106)$ & $12 \%(106)$ & \\
\hline & ARSA & $79 \%(108)$ & $4 \%(108)$ & $17 \%(108)$ & \\
\hline & LSI DiGeorge/VCFS and ARSA & & & & $60 \%(101)$ \\
\hline \multirow[t]{3}{*}{$24, F$} & LSI DiGeorge/VCFS & $79 \%(111)$ & $6 \%(111)$ & $15 \%(111)$ & \\
\hline & ARSA & $75 \%(113)$ & $10 \%(113)$ & $15 \%(113)$ & \\
\hline & LSI DiGeorge/VCFS and ARSA & & & & $53 \%(105)$ \\
\hline \multirow[t]{3}{*}{$25, F$} & LSI DiGeorge/VCFS & $88 \%(103)$ & $2 \%(103)$ & $10 \%(103)$ & \\
\hline & ARSA & $76 \%(104)$ & $5 \%(104)$ & $19 \%(104)$ & \\
\hline & LSI DiGeorge/VCFS and ARSA & & & & $57 \%(103)$ \\
\hline \multirow[t]{2}{*}{$26, F$} & $\begin{array}{l}\text { LSI DiGeorge/VCFS } \\
A R S A\end{array}$ & $81 \%(117)$ & $2 \%(117)$ & $\begin{array}{l}17 \%(117) \\
20 \%(115)\end{array}$ & \\
\hline & LSI DiGeorge/VCFS and ARSA & 78\% (115) & $2 \%(115)$ & $20 \%$ (115) & $50 \%(113)$ \\
\hline \multirow[t]{3}{*}{$27, M$} & LSI DiGeorge/VCFS & $84 \%(117)$ & $0 \%(117)$ & $16 \%(117)$ & \\
\hline & ARSA & $78 \%(118)$ & $3 \%(118)$ & $19 \%(118)$ & \\
\hline & LSI DiGeorge/VCFS and ARSA & & & & $49 \%(113)$ \\
\hline \multirow[t]{3}{*}{$28, M$} & LSI DiGeorge/VCFS & $85 \%(114)$ & $2 \%(114)$ & $13 \%(114)$ & \\
\hline & ARSA & $83 \%(115)$ & $2 \%(115)$ & $15 \%(115)$ & \\
\hline & LSI DiGeorge/VCFS and ARSA & & & & $58 \%(112)$ \\
\hline \multirow[t]{3}{*}{$29, M$} & LSI DiGeorge/VCFS & $88 \%(104)$ & $3 \%(104)$ & $9 \%(104)$ & \\
\hline & ARSA & $83 \%(104)$ & $4 \%(104)$ & $13 \%(104)$ & \\
\hline & LSI DiGeorge/VCFS and ARSA & & & & $53 \%(99)$ \\
\hline \multirow[t]{3}{*}{$30, M$} & LSI DiGeorge/VCFS & $80 \%(108)$ & $1 \%(108)$ & $19 \%(108)$ & \\
\hline & ARSA & $71 \%(108)$ & $2 \%(108)$ & $27 \%(108)$ & \\
\hline & LSI DiGeorge/VCFS and ARSA & & & & $51 \%(107)$ \\
\hline \multicolumn{6}{|c|}{ 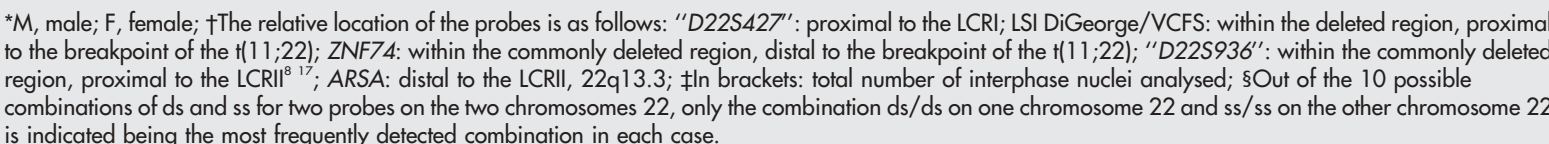 } \\
\hline
\end{tabular}

origin of the translocation (individuals 34, 35, and 36). The mean percentage of ds/ss obtained with the LSI DiGeorge/ VCFS probe for the eight individuals with translocations was 83.9\% (95\% CI: 76.9 to 90.8 ). The mean percentages of ds/ss obtained with the ARSA probe in the individuals with a paternal origin of the translocation (individuals 34-36) was $35.7 \%$ (95\% CI: 17.0 to 54.3 ) and $82.4 \%$ in the remaining five individuals with translocations (95\% CI: 72.4 to 92.4 ).

The values observed in the 10 cases with structurally normal chromosomes 22 were comparable to those obtained in individuals with a translocation and those with a $22 \mathrm{q} 11.2$ deletion. Two-sample $t$ tests were performed and resulted in non-significant differences between the following groups: (a) results for the LSI DiGeorge/VCFS probe in the 10 control individuals versus the eight individuals with translocations: $\mathrm{p}=0.81$; (b) results for the ARSA probe in the 10 control individuals versus five individuals with translocations (not considering individuals 34-36): $\mathrm{p}=0.095$. On the other hand, the probes mapping to the derivative chromosome 11 in the three individuals with a paternal origin of the translocation showed a strongly significant reduction in the percentage of nuclei with ds/ss (two-sample $t$ test with the results for the
ARSA probe in the 10 control individuals $21-30$ versus individuals 34-36: $\mathrm{p}<0.0001$ ).

On the basis of these results it appears that the asynchronous replication at this region is a general phenomenon and is not an effect of either translocations or deletions. Differences in the replication timing were only seen for $22 \mathrm{q}$ regions translocated onto another chromosome in three cases. No major changes in the replication timing at $22 \mathrm{q} 11.2$ were observed in the other cases with translocations and deletions compared to control individuals. This legitimates the use of such structurally abnormal chromosomes 22 for investigation of the randomness of the asynchronous replication. It should be stressed that our results cannot exclude minor changes in the replication timing due to translocations or deletions, however, the investigation of such minor changes is beyond the scope of this study.

The three further shorter probes we generated (that is, "D22S427" proximal to the LCRI; and ZNF74 and "D22S936", both mapping within the commonly deleted region distal to the breakpoint of the $\left.t(11 ; 22)^{8}{ }^{17}\right)$, used on a subset of individuals, resulted in percentages of nuclei with ds/ss comparable to those obtained with the commercially 
Table 4 Interphase nuclei of individuals with a structurally abnormal chromosome 22 showing a double (ds) and a single signal (ss) for probes within the commonly deleted $22 q 11.2$ region and at flanking positions

\begin{tabular}{|c|c|c|c|c|c|c|c|}
\hline \multirow{2}{*}{$\begin{array}{l}\text { Case, } \\
\text { gender* }\end{array}$} & \multirow{2}{*}{$\begin{array}{l}\text { Chromosomes } 22 \\
\text { (denoted A and B) }\end{array}$} & \multirow[b]{2}{*}{ FISH probest } & \multirow{2}{*}{$\begin{array}{l}\text { Derivative } \\
\text { chromosomes } \\
\text { on which the 22q } \\
\text { probes hybridise } \\
\text { (chromosomes "A") }\end{array}$} & \multicolumn{3}{|c|}{$\begin{array}{l}\text { Interphase nuclei showing ds/ss for } \\
\text { single probes } \$ \text { or } 2 \times d s \text { on one chr. } \\
22 \text { and } 2 \times s s \text { on the other chr. } 22 \\
\text { for combinations of two probes } \Phi\end{array}$} & \multirow[b]{2}{*}{ Interpretation and comment } \\
\hline & & & & $d s$ on $A$ & ds on $B$ & Totalł & \\
\hline $31, \mathrm{~F}$ & $\begin{array}{l}\text { A: } 1(6 ; 22)(q 26 ; q 11.2) \\
\text { mat; } \\
\text { B: structurally normal }\end{array}$ & $\begin{array}{l}\text { LSI DiGeorge/VCFS } \\
\text { ARSA } \\
\text { LSI DiGeorge/VCFS and } \\
\text { ARSA }\end{array}$ & $\begin{array}{l}\text { der } 22 \\
\text { der } 6\end{array}$ & $\begin{array}{l}24 \% \\
24 \% \\
19 \%\end{array}$ & $\begin{array}{l}59 \% \\
55 \% \\
49 \%\end{array}$ & $\begin{array}{l}83 \%(122) \\
79 \%(122) \\
68 \%\end{array}$ & $\begin{array}{l}\text { Non-random asynchronous } \\
\text { replication: paternal } \\
\text { chromosome } 22 \text { early } \\
\text { replicating }\end{array}$ \\
\hline $32, F$ & $\begin{array}{l}\text { A: } t(11 ; 22)(q 23 ; q 11.2) \text {; } \\
\text { B: structurally normal }\end{array}$ & $\begin{array}{l}\text { "D22S427" } \\
\text { LSI DiGeorge/VCFS } \\
\text { ZNF74 } \\
\text { "D22S936" } \\
\text { ARSA } \\
\text { "D22S427" and ZNF74 } \\
\text { "D22S427" and } \\
\text { "D22S936" } \\
\text { "D22S427" and ARSA } \\
\text { LSI DiGeorge/VCFS and } \\
\text { ARSA }\end{array}$ & $\begin{array}{l}\text { der } 22 \\
\text { der } 22 \\
\text { der } 11 \\
\text { der } 11 \\
\text { der } 11\end{array}$ & $\begin{array}{l}4 \% \\
26 \% \\
6 \% \\
0 \\
5 \% \\
2 \% \\
0 \\
0 \\
0\end{array}$ & $\begin{array}{l}69 \% \\
63 \% \\
47 \% \\
62 \% \\
65 \% \\
45 \% \\
52 \% \\
\\
61 \% \\
63 \%\end{array}$ & $\begin{array}{l}73 \%(307) \\
89 \%(102) \\
53 \%(115) \\
62 \%(107) \\
70 \%(169) \\
47 \%(105) \\
52 \%(107) \\
61 \%(88) \\
63 \%(81)\end{array}$ & $\begin{array}{l}\text { Non-random asynchronous } \\
\text { replication }\end{array}$ \\
\hline $33, F$ & $\begin{array}{l}\text { A: } t(11 ; 22)(q 23 ; q 11.2) \text {; } \\
\text { B: structurally normal }\end{array}$ & $\begin{array}{l}\text { LSI DiGeorge/VCFS } \\
\text { ARSA } \\
\text { LSI DiGeorge/VCFS and } \\
\text { ARSA }\end{array}$ & $\begin{array}{l}\text { der } 22 \\
\text { der } 11\end{array}$ & $\begin{array}{l}24 \% \\
24 \% \\
22 \%\end{array}$ & $\begin{array}{l}69 \% \\
65 \% \\
64 \%\end{array}$ & $\begin{array}{l}93 \%(98) \\
89 \%(93) \\
86 \%(93)\end{array}$ & $\begin{array}{l}\text { Non-random asynchronous } \\
\text { replication }\end{array}$ \\
\hline $34, M$ & $\begin{array}{l}\text { A: } t(11 ; 22)(q 23 ; q 11.2) \\
\text { pat; } \\
\text { B: structurally } \\
\text { normal }\end{array}$ & $\begin{array}{l}\text { LSI DiGeorge/VCFS } \\
\text { ARSA } \\
\text { LSI DiGeorge/VCFS and } \\
\text { ARSA }\end{array}$ & $\begin{array}{l}\text { der } 22 \\
\text { der } 11\end{array}$ & $\begin{array}{l}48 \% \\
21 \% \\
10 \%(52 \% \\
\text { A: ds-ss; B: } \\
\text { ss-ss) }\end{array}$ & $\begin{array}{l}18 \% \\
19 \% \\
0\end{array}$ & $\begin{array}{l}66 \%(152) \\
40 \%(102) \\
10 \%(102)\end{array}$ & $\begin{array}{l}\text { Non-random asynchronous } \\
\text { replication: paternal } \\
\text { chromosome } 22 \text { early } \\
\text { replicating }\end{array}$ \\
\hline $35, M$ & $\begin{array}{l}\text { First son of } \\
\text { case } 34 ; \\
\text { A: } t(11 ; 22)(q 23 ; q 11.2) \\
\text { pat; } \\
\text { B: structurally } \\
\text { normal }\end{array}$ & $\begin{array}{l}\text { "D22S427" } \\
\text { LSI DiGeorge/VCFS } \\
\text { ZNF74 } \\
\text { "D22S936" } \\
\text { ARSA } \\
\text { "D22S427" and ZNF74 } \\
\text { "D22S427" and } \\
\text { "D22S936" } \\
\text { "D22S427" and ARSA } \\
\text { LSI DiGeorge/VCFS and } \\
\text { ARSA }\end{array}$ & $\begin{array}{l}\text { der } 22 \\
\text { der } 22 \\
\text { der } 11 \\
\text { der } 11 \\
\text { der } 11\end{array}$ & $\begin{array}{l}59 \% \\
61 \% \\
10 \% \\
3 \% \\
14 \% \\
2 \% \\
2 \% \\
\\
3 \% \\
11 \%(63 \% \\
\text { A: ds-ss; } \\
\text { B: ss-ss) }\end{array}$ & $\begin{array}{l}11 \% \\
20 \% \\
17 \% \\
6 \% \\
13 \% \\
3 \% \\
3 \% \\
\\
2 \% \\
0\end{array}$ & $\begin{array}{l}70 \%(316) \\
81 \%(123) \\
27 \%(109) \\
9 \%(104) \\
27 \%(210) \\
5 \%(106) \\
5 \%(104) \\
\\
5 \%(103) \\
11 \%(107)\end{array}$ & $\begin{array}{l}\text { Non-random asynchronous } \\
\text { replication for the probes } \\
\text { proximal to the translocation } \\
\text { breakpoint: paternal } \\
\text { chromosome } 22 \text { early } \\
\text { replicating; } \\
\text { Segment of chromosome } 22 \\
\text { distal to the translocation } \\
\text { breakpoint no longer } \\
\text { asynchronous replicating }\end{array}$ \\
\hline $36, M$ & $\begin{array}{l}\text { Second son of case } 34 ; \\
\text { A: } t(11 ; 22)(q 23 ; q 11.2) \\
\text { pat; } \\
\text { B: structurally normal }\end{array}$ & $\begin{array}{l}\text { LSI DiGeorge/VCFS } \\
\text { ARSA } \\
\text { LSI DiGeorge/VCFS } \\
\text { and ARSA }\end{array}$ & $\begin{array}{l}\text { der } 22 \\
\text { der } 11\end{array}$ & $\begin{array}{l}50 \% \\
10 \% \\
10 \%(55 \% \\
\text { A: ds-ss; } \\
\text { B: ss-ss) }\end{array}$ & $\begin{array}{l}32 \% \\
30 \% \\
0\end{array}$ & $\begin{array}{l}82 \%(135) \\
40 \%(100) \\
10 \%(100)\end{array}$ & $\begin{array}{l}\text { Non-random asynchronous } \\
\text { replication: paternal } \\
\text { chromosome } \\
22 \text { early replicating }\end{array}$ \\
\hline $37, \mathrm{~F}$ & $\begin{array}{l}\text { A: } t(19 ; 22)(p 13.3 ; q 11.2) \text {; } \\
\text { B: structurally normal }\end{array}$ & $\begin{array}{l}\text { iSI DiGeorge/VCFS } \\
\text { ARSA } \\
\text { LSI DiGeorge/VCFS } \\
\text { and ARSA }\end{array}$ & $\begin{array}{l}\text { der } 22 \\
\text { der } 19\end{array}$ & $\begin{array}{l}26 \% \\
29 \% \\
25 \%\end{array}$ & $\begin{array}{l}62 \% \\
56 \% \\
50 \%\end{array}$ & $\begin{array}{l}88 \%(100) \\
85 \%(100) \\
75 \%(100)\end{array}$ & $\begin{array}{l}\text { Non-random asynchronous } \\
\text { replication }\end{array}$ \\
\hline $38, F$ & $\begin{array}{l}\text { Daughter of case } 37 ; \\
\text { A: }+(19 ; 22) \\
\text { (p13.3; } 11.2) ; \\
\text { B: structurally normal }\end{array}$ & $\begin{array}{l}\text { LSI DiGeorge/VCFS } \\
\text { ARSA } \\
\text { LSI DiGeorge/VCFS } \\
\text { and ARSA }\end{array}$ & $\begin{array}{l}\text { der } 22 \\
\text { der } 19\end{array}$ & $\begin{array}{l}29 \% \\
28 \% \\
24 \%\end{array}$ & $\begin{array}{l}60 \% \\
61 \% \\
53 \%\end{array}$ & $\begin{array}{l}89 \%(100) \\
89 \%(100) \\
77 \%(100)\end{array}$ & $\begin{array}{l}\text { Non-random asynchronous } \\
\text { replication: paternal } \\
\text { chromosome } 22 \text { early } \\
\text { replicating }\end{array}$ \\
\hline $13, F$ & $\begin{array}{l}\text { A: maternal } 22 q 11.2 \\
\text { deletion; } \\
\text { B: structurally normal }\end{array}$ & $\begin{array}{l}\text { "D22S427" } \\
\text { ARSA } \\
\text { "D22S427" and ARSA" }\end{array}$ & $\begin{array}{l}\text { der } 22 \\
\text { der } 22\end{array}$ & $\begin{array}{l}3 \% \\
6 \% \\
2 \%\end{array}$ & $\begin{array}{l}66 \% \\
62 \% \\
51 \%\end{array}$ & $\begin{array}{l}69 \%(117) \\
68 \%(117) \\
53 \%(117)\end{array}$ & $\begin{array}{l}\text { Non-random asynchronous } \\
\text { replication: paternal } \\
\text { chromosome } 22 \text { early } \\
\text { replicating }\end{array}$ \\
\hline $17, \mathrm{~F}$ & $\begin{array}{l}\text { A: paternal } 22 q 11.2 \\
\text { deletion; } \\
\text { B: structurally normal }\end{array}$ & $\begin{array}{l}\text { "D22S427" } \\
\text { ARSA } \\
\text { "D22S427" and ARSA" }\end{array}$ & $\begin{array}{l}\text { der } 22 \\
\text { der } 22\end{array}$ & $\begin{array}{l}65 \% \\
60 \% \\
50 \%\end{array}$ & $\begin{array}{l}2 \% \\
8 \% \\
1 \%\end{array}$ & $\begin{array}{l}67 \%(78) \\
68 \%(78) \\
51 \%(78)\end{array}$ & $\begin{array}{l}\text { Non-random asynchronous } \\
\text { replication: paternal } \\
\text { chromosome } 22 \text { early } \\
\text { replicating }\end{array}$ \\
\hline
\end{tabular}

"M, male; F, female; TThe relative location of the probes is as follows: "D22S427": proximal to the LCRI; LSI DiGeorge/VCFS: within the deleted region, proximal to the breakpoint of the $t(11 ; 22)$; ZNF74: within the commonly deleted region, distal to the breakpoint of the $t(11 ; 22)$; "D22S936": within the commonly deleted region, proximal to the LCRII $(8,17)$; ARSA: distal to the LCRII, 22q13.3; †ln brackets: total number of interphase nuclei analysed; §The cells with ds/ss, ds/ds and $\mathrm{ss} / \mathrm{ss}$ were scored, but only the percentage with $\mathrm{ds} / \mathrm{ss}$ is indicated, being the value of relevance in this context; ${ }^{-}$Out of the 16 possible combinations of $d s$ and ss for two probes on the two chromosomes 22 , the combination $\mathrm{ds} / \mathrm{ds}$ on one chromosome 22 and ss/ss on the other chromosome 22 is indicated being the most frequently detected combination in most cases (additional data are indicated in cases 34-36 where another combination was more frequent). 
available probes (tables 3 and 4). Illustrative examples of interphase nuclei showing double/single signals are shown in fig 1 .

The use of combinations of two different probes revealed that the double signals for both probes were most frequently observed on the same chromosome (tables 3 and 4). Thus, the entire region ranging from at least $22 \mathrm{ql} 1.2$ (proximal to the LCRI) to $22 \mathrm{q} 13.3$ appears to replicate asynchronously.

Four different control regions showed the expected proportion of ds/ss in interphase nuclei in two control individuals with structurally normal chromosomes. The control regions where synchronous replication is expected were the ELN locus on chromosome $7 \mathrm{ql} 1.23$ (ds/ss in 19\% and $21 \%$ of interphase nuclei in cases 21 and 22 , respectively, example in fig 1B), and a probe at 5pl5.2 spanning D5S23D5S721 (ds/ss: $13 \%$ and 18\%, respectively, in cases 21 and 22 , data not shown). Control regions where asynchronous replication is expected were the LSI Prader-Willi/Angelman Region Probe (SNRPN) at 15q12 (ds/ss: $42 \%$ and 39\%, respectively, in individuals 21 and 22, data not shown), and the LSI Steroid Sulfatase (STS) probe at Xp22.3 (ds/ss: $36 \%$ and $38 \%$, respectively, in individuals 21 and 22 , data not shown). The number of interphase nuclei investigated in each case ranged from 100 to 115.

\section{Non-random asynchronous replication: early replication of the paternal $22 q 11.2$ allele}

According to our proposed model (fig 2) we would expect the asynchronous replication at $22 \mathrm{ql} 1.2$ to be non-random. The total percentages of nuclei with $\mathrm{ds} / \mathrm{ss}$ are indicated in table 4 for the 10 individuals with a structurally abnormal chromosome 22 (cases 31-38, 13, and 17). In addition, the proportion is given as to which chromosome 22 carries the double signal (that is, the derivative chromosomes or the structurally normal 22). In the case of a random asynchronous replication double signals would be evenly distributed between the two chromosomes 22. This was not the case for any of the 10 individuals listed in table 4. The LSI DiGeorge/
A

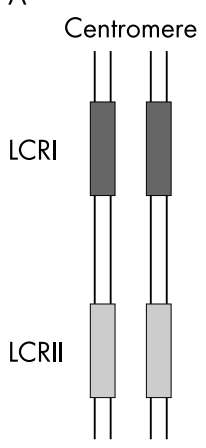

Telomere
B

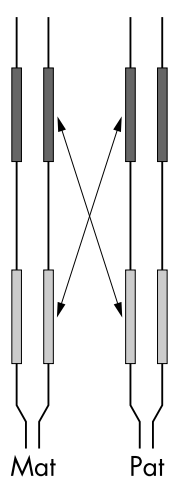

C

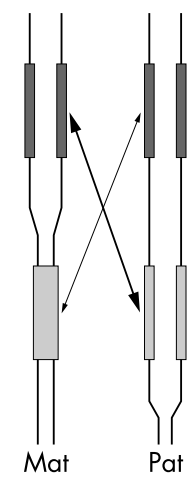

Figure 2 Schematic representation of mispairing in a situation with asynchronous replication. (A) The genomic segment encompassing the $22 q 11.2$ deletion is schematically illustrated. The proximal block of lowcopy repeats (LCRI) and the distal repeat (LCRII) are the positions at which mispairing occurs. For the sake of clarity only one of the distal breakpoints is depicted. (B) In a situation where the two parental alleles (Mat: maternal, Pat: paternal) replicate synchronously, or in the case of random asynchronous replication, the repeats LCRI and LCRII from both chromosomes are free to mispair with one another. No bias in the origin of the proximal and distal regions would be expected. (C) In a situation where the paternal chromosome replicates earlier, mispairing of the paternal LCRII with the maternal LCRI would be possible at a time when the maternal LCRII has not yet gone through replication. A bias in favour of a grandmaternal origin of the proximal region flanking the $22 q 11.2$ deletion would be expected in the patients.
VCFS probe showed in all eight cases with translocations a preferential occurrence of the ds on either the structurally normal chromosome 22 (five cases) or the derivative chromosomes 22 (the three cases with a paternal origin of the translocation). The bias in the distribution of the ds in favour of a specific chromosome 22 was statistically significant: (a) eight cases (31-38), LSI DiGeorge/VCFS probe: the mean value of the higher percentages was $59 \%$ (95\% CI: 53.2 to 64.8 ) and for the lower percentages $24.9 \%$ (95\% CI: 21.1 to 28.7 ), paired-sample $t$ test: $\mathrm{p}<0.0001$; (b) five cases (31-33, 37, and 38), ARSA probe: the mean value of the higher percentages was $60.4 \%$ (95\% CI: 54.5 to 66.3 ) and for the lower percentages $22.0 \%$ (95\% CI: 9.9 to 34.1 ), pairedsample $t$ test: $\mathrm{p}=0.003$. A non-random pattern of asynchronous replication was also observed in the two patients with a 22 q11.2 deletion, individuals 13 and 17, with an early replication of the structurally normal chromosome 22 in the former case and of the chromosome bearing the deletion in the latter case.

Importantly, the paternal allele was earlier replicating in all cases where the parental origin of the chromosomes 22 was known (five cases with a translocation and two cases with a 22q11.2 deletion; table 4).

\section{DISCUSSION}

We detected comparable levels of asynchronous replication at 22 q11.2 in all tested individuals, that is, control individuals and carriers of either translocations or deletions involving the 22 q11.2 region. Based on cases with distinguishable chromosomes 22 we show a non-random nature of the asynchronous replication. In all cases where the origin of the structurally abnormal chromosome 22 was known we detected an earlier replication of the paternal alleles. We hypothesise that a nonrandom asynchronous replication in this region represents a risk factor for the formation of the 22q11.2 deletion by increasing the probability of an initial mispairing of the parental alleles at the highly homologous low-copy repeats. These initial abnormal conformations may lead, later in meiosis, to an unequal meiotic crossover and thus to the 22q11.2 deletion.

The replication timing results presented here were performed on peripheral blood cells. Our hypothesis would imply that the non-random asynchronous replication also occurs in gametogenesis. In mice it has been shown that the non-random asynchronous replication at imprinted genes is established in gametogenesis and is maintained throughout development in a wide range of tissues. ${ }^{20}$ The random asynchronous replication observed for example at the murine olfactory receptor loci and B cells occurs before meiosis in gametes, is erased after fertilisation, and is then reset before implantation of the embryo. ${ }^{6}$ Our results represent the first example of non-random asynchronous replication apparently not associated with imprinted genes. It would be interesting to investigate whether this phenomenon also occurs in mice or other model organisms in order to investigate in detail the setting of the non-random asynchronous replication at such loci.

A growing number of researchers have recently reported on their results regarding replication timing using cell cycle fractionation. $^{21} 22$ The replication timing results obtained using different techniques are generally in agreement. ${ }^{21} 22$ Exceptions have been reported at heterochromatic regions and at timing-switch boundaries. At such regions there appears to be a delayed resolution of the sister chromatids, which would appear in FISH analysis as a singlet and would be misleading as to the actual replication timing. ${ }^{41}$ A delayed chromatid resolution could also be due amongst other factors to the pausing of the replication fork or to long replicons that are still undergoing replication. Indeed, the FISH based 
method is not a measurement of replication itself but rather of the sister chromatid resolution. However, FISH analysis remains appropriate for analyses of the replication timing when these are aimed at detecting asynchrony and particularly a possible non-randomness of the phenomenon. In this study we obtained an extremely high level of nuclei showing $\mathrm{ds} / \mathrm{ss}$ using probes for 22q11.2-q13.3, whilst eight measurements at control regions resulted in ratios of $\mathrm{ds} / \mathrm{ss}$ in agreement with published data. ${ }^{256}$ It is possible that, in a subset of nuclei, replication at $22 \mathrm{q}$ had actually already occurred on both homologues but one chromosome showed a delayed chromatid resolution. This is in itself intriguing as the parental alleles clearly behave differently in the $\mathrm{S}$ phase, thus excluding that the high level of ds/ss is simply due to artefacts such as properties of probes or domain specific resolution.

The sizes of the mammalian replication units have been estimated to range from about $50 \mathrm{~kb}$ up to $1 \mathrm{Mb}^{23}$ Replication at each fork is estimated to proceed at about $2 \mathrm{~kb}$ per minute in mammalian cells. ${ }^{24}$ The replication timing appears to be organised in large-scale replication domains of about $1 \mathrm{Mb}$ and sequence elements controlling the initiation of replication may be located at many $\mathrm{kb}$ distant from the primary origin. ${ }^{25}{ }^{26}$ The long arm of chromosome 22 appears to have large segments of several $\mathrm{Mb}$ which replicate early in S phase. ${ }^{22}$ Thus, the replicons covering the 22q11.2 commonly deleted region appear to be part of a large-scale replication domain. We attempted to extrapolate the relative position of the relevant time-switching element(s) from the data obtained for the patients with a 22q11.2 deletion and the patients with a $t(11 ; 22)$. Asynchronous replication was maintained in both patients with a 22q11.2 deletion, indicating that the relevant time-switching element(s) appears to lie outside the deleted region. Analysis of cases with a translocation $(11 ; 22)$ showed that early replication of the structurally normal chromosome 22 was observed for all tested 22q probes in individual 32. On the other hand, early replication of the paternal alleles of individuals 34-36 was restricted to the probes mapping to the derivative 22 chromosome (that is, proximal to the translocation breakpoint: "D22S427" and LSI DiGeorge/VCFS probe). ${ }^{17}$ The chromosome 22 segments distal to the breakpoint, which were translocated onto chromosome 11, showed a strongly significant decrease in ds/ss signals (table 4). Therefore, we suggest that the relevant time-switching element(s) responsible for the non-random asynchronous replication at 22q11.2 lies proximal to the LCRI.

Several recent publications report on the intimate coupling of DNA replication, genome stability, and meiotic recombinations in yeast. ${ }^{27-31}$ Although a tight coupling of replication and meiotic recombination has not yet been shown in mammals, certain key proteins in yeast, such as Rec8p, are conserved in a wide range of organisms including humans. ${ }^{32}$

One of the control regions investigated in this study was the ELN locus on chromosome 7q11.23, which is of particular interest for several reasons. As mentioned above, the $1.5 \mathrm{Mb}$ deletion at human $7 \mathrm{ql} 1.23$ represents a further frequently observed interstitial deletion, which is also known to be associated with unequal meiotic recombination events. ${ }^{9}{ }^{10} \mathrm{We}$ performed haplotype analysis for 36 patients with de novo $7 q 11.23$ deletions. A meiotic recombination was detected in 23 out of 36 cases. Unlike the situation observed for the $22 \mathrm{ql} 1.2$ deletions, the flanking regions at $7 \mathrm{q} 11.23$ originated almost equally from the two grandparents (the proximal region was derived from the grandmother in 13 cases and from the grandfather in 10 cases, data not shown). Clearly, haplotype analysis at the breakpoints would only show an uneven distribution of the origin of the proximal and distal regions in cases with a non-random allelic exclusion, but not in the case of a random asynchronous replication. Although the percentage of cells with ds/ss we obtained for the control individuals was in the range indicative of synchronous replication, it would be very interesting to investigate the replication timing in individuals with the inversion polymorphism.

With an incidence of about 1 in 4000 newborns, ${ }^{33}$ the $22 \mathrm{q} 11.2$ deletion is the most frequently occurring microdeletion in humans. Whether or not asynchronous replication, random or non-random, also favours the mispairing of other low-copy repeats remains to be investigated.

\section{ACKNOWLEDGEMENTS}

We wish to thank the patients, their parents, and all control individuals for their cooperation.

We are grateful to Professor T Gasser and Dr V Rousson, Department of Biostatistics, University of Zurich, for their assistance with the statistical evaluations.

\section{Authors' affiliations}

A Baumer, M Riegel, A Schinzel, Institute of Medical Genetics, University of Zurich, Schwerzenbach, Switzerland

This study was supported in part by the Swiss National Foundation (grant numbers: 3100-056956.99 and 32-56051.98).

Conflict of interest: none declared.

${ }^{*}$ The authors $A B$ and $M R$ contributed equally to this work.

\section{REFERENCES}

1 Schmidt M, Migeon BR. Asynchronous replication of homologous loci on human active and inactive X chromosomes. Proc Natl Acad Sci U S A 1990;87(10):3685-9.

2 Kitsberg D, Selig S, Brandeis M, Simon I, Keshet I, Driscoll DJ, Nicholls RD, Cedar $\mathrm{H}$. Allele-specific replication timing of imprinted gene regions. Nature 1993;364(6436):459-63.

3 Efstradiadis A. A new whiff of monoallelic expression. Curr Biol 1995;5:21-4.

4 Selig S, Okumura K, Ward DC, Cedar H. Delineation of DNA replication time zones by fluorescence in situ hybridization. EMBO J 1992;11(3):1217-25.

5 Chess A, Simon I, Cedar H, Axel R. Allelic inactivation regulates olfactory receptor gene expression. Cell 1994;78(5):823-34

6 Mostoslavsky R, Singh N, Tenzen T, Goldmit M, Gabay C, Elizur S, Qi P, Reubinoff BE, Chess A, Cedar H, Bergman Y. Asynchronous replication and allelic exclusion in the immune system. Nature 2001;414(6860):221-5.

7 Schinzel AA, Basaran S, Bernasconi F, Karaman B, Yuksel-Apak M, Robinson WP. Maternal uniparental disomy 22 has no impact on the phenotype. Am J Hum Genet 1994;54(1):21-4.

8 Shaikh TH, Kurahashi H, Saitta SC, O'Hare AM, Hu P, Roe BA, Driscoll DA, McDonald-McGinn DM, Zackai EH, Budarf ML, Emanuel BS. Chromosome 22 -specific low copy repeats and the 22q11.2 deletion syndrome: genomic organization and deletion endpoint analysis. Hum Mol Genet 2000;9(4):489-501.

9 Baumer A, Dutly F, Balmer D, Riegel M, Tukel T, Krajewska-Walasek M, Schinzel AA. High level of unequal meiotic crossovers at the origin of the $22 q 11.2$ and 7 q1 1.23 deletions. Hum Mol Genet 1998;7(5):887-94.

10 Dutly F, Schinzel A. Unequal interchromosomal rearrangements may result in elastin gene deletions causing the Williams-Beuren syndrome. Hum Mol Genet 1996;5(12):1893-8.

11 Osborne LR, Li M, Pober B, Chitayat D, Bodurtha J, Mandel A, Costa T, Grebe T, Cox S, Tsui LC, Scherer SW. A 1.5 million-base pair inversion polymorphism in families with Williams-Beuren syndrome. Nat Genet 2001;29(3):321-5

12 Gimelli G, Pujana MA, Patricelli MG, Russo S, Giardino D, Larizza L, Cheung J, Armengol L, Schinzel A, Estivill X, Zuffardi O. Genomic inversions of human chromosome 15q11-q13 in mothers of Angelman syndrome patients with class II (BP2/3) deletions. Hum Mol Genet 2003;12(8):849-58.

13 Gebhardt GS, Devriendt K, Thoelen R, Swillen A, Pijkels E, Gewillig M, Fryns JP, Vermeesch JR. No evidence for a parental inversion polymorphism predisposing to rearrangements at 22q11.2 in the DiGeorge/velocardiofacial syndrome. Eur J Hum Genet 2003;1 1(2):109-111.

14 Inoue K, Dewar K, Katsanis N, Reiter LT, Lander ES, Devon KL, Wyman DW, Lupski JR. The 1.4-Mb CMT1A duplication/HNPP deletion genomic region reveals unique genome architectural features and provides insights into the recent evolution of new genes. Genome Res 2001;11(6):1018-33.

15 Bi W, Yan J, Stankiewicz P, Park SS, Walz K, Boerkoel CF, Potocki L, Shaffer LG, Devriendt K, Nowaczyk MJ, Inoue K, Lupski JR. Genes in a refined Smith-Magenis syndrome critical deletion interval on chromosome 17p11.2 and the syntenic region of the mouse. Genome Res 2002;12(5):713-28.

16 Wegner RD. Diagnostic cytogenetics. Berlin: Springer, 1999.

17 Kurahashi H, Shaikh TH, Hu P, Roe BA, Emanuel BS, Budarf ML. Regions of genomic instability on $22 q 11$ and $11 \mathrm{q} 23$ as the etiology for the recurrent constitutional $+(11 ; 22)$. Hum Mol Genet 2000;9(11):1665-70. 
18 Hadlaczky G, Went M Ringertz NR. Direct evidence for the non-random localization of mammalian chromosomes in the interphase nucleus. Exp Cell Res 1986;167(1):1-15.

19 Hager HD, Schroeder-Kurth TM, Vogel F. Position of chromosomes in the human interphase nucleus. An analysis of nonhomologous chromatid translocations in lymphocyte cultures after Trenimon treatment and from patients with Fanconi's anemia and Bloom's syndrome. Hum Genet 1982:61(4):342-56.

20 Simon I, Tenzen T, Reubinoff BE, Hillman D, McCarrey JR, Cedar H. Asynchronous replication of imprinted genes is established in the gametes and maintained during development. Nature 1999;401(6756):929-32.

21 Azuara V, Brown KE, Williams RRE, Webb N, Dillon N, Festenstein R, Buckle $V$, Merkenschlager M, Fisher AG. Heritable gene silencing in lymphocytes delays chromatid resolution without affecting the timing of DNA replication. Nat Cell Biol 2003;5(7):668-74.

22 Woodfine K, Fiegler H, Beare DM, Collins JE, McCann OT, Young BD Debernardi S, Mott R, Dunham I, Carter NP. Replication timing of the human genome. Hum Mol Genet 2004; 13(2): 191-202.

23 Liapunova NA. Organization of replication units and DNA replication in mammalian cells as studied by DNA fiber autoradiography. Int Rev Cytol 1994; 154:261-6.

24 Edenberg HJ, Huberman JA. Eukaryotic chromosome replication. Annu Rev Genet 1975;9:245-84

25 Nogami M, Nogami O, Kagotani K, Okumura M, Taguchi H, Ikemura T, Okumura K. Intranuclear arrangement of human chromosome 12 correlates to large-scale replication domains. Chromosoma 2000;108:514-22.
26 Cimbora DM, Schübeler D, Reik A, Hamilton J, Francastel C, Epner EM, Groudine M. Long-distance control of origin choice and replication timing in the human beta-globin locus are independent of the locus control region. Mol Cell Biol 2000;20(15):5581-91.

27 Chen C, Kolodner RD. Gross chromosomal rearrangements in Saccharomyces cerevisiae replication and recombination defective mutants. Nat Genet 1999;23:81-5.

28 Myung K, Pennaneach V, Kats ES, Kolodner RD. Saccharomyces cerevisiae chromatin-assembly factors that act during DNA replication function in the maintenance of genome stability. Proc Natl Acad Sci U S A 2003; 100(11):6640-5

29 Borde V, Goldman ASH, Lichten M. Direct coupling between meiotic DNA replication and recombination initiation. Science 2000;290:806-9.

30 Murakami H, Borde V, Shibata T, Lichten M, Ohta K. Correlation between premeiotic DNA replication and chromatin transition at yeast recombination initiation sites. Nucleic Acids Res 2003;31(14):4085-90.

31 Cha RS, Weiner BM, Keeney S, Dekker J, Kleckner N. Progression of meiotic DNA replication is modulated by interchromosomal interaction proteins, negatively by Spol $1 \mathrm{p}$ and positively by Rec8p. Genes Dev 2000; 14:493-503.

32 Parisi S, McKay M, Molnar M, Thompson M, van der Spek $P$, van DrunenSchoenmaker E, Kanaar R, Lehmann E, Hoeijmakers J, Kohli J. Rec8p, a meiotic recombination and sister chromatid cohesion phosphoprotein of the Rad21 p family conserved from fission yeast to humans. Mol Cell Biol 1999: 19:3515-28.

33 Devriendt K, Fryns JP, Mortier G, van Thienen MN, Keymolen K. The annual incidence of DiGeorge/velocardiofacial syndrome. J Med Genet 1998:35(9):789-90. 